\title{
Understanding Persistence in the Resistance
}

Authors: Dana R. Fisher ${ }^{1}$ and Lorien Jasny ${ }^{2}$

\begin{abstract}
Since Donald Trump's Inauguration, large-scale protest events have taken place around the US, with many of the biggest events being held in Washington, DC. The streets of the nation's capital have been flooded with people marching about a diversity of progressive issues including women's rights, climate change, and gun violence. Although research has found that these events have mobilized a high proportion of repeat participants who come out again-and-again, limited research has focused on understanding differential participation in protest, especially during one cycle of contention. This paper, accordingly, explores the patterns among the protest participants to understand differential participation and what explains persistence in the Resistance. In it, we analyze a unique dataset collected from surveys conducted with a random sample of protest participant at the largest protest events in Washington, DC since the inauguration of Donald Trump. Our findings provide insights into repeat protesters during this cycle of contention. The paper concludes by discussion how our findings contribute to the research on differential participation and persistence.
\end{abstract}

Keywords: protest, social movements, mobilization, persistence, the Resistance,

\footnotetext{
1 Department of Sociology, University of Maryland, 2112 Parren Mitchell Art-Sociology Building 3834 Campus Drive, College Park, MD 20742, drfisher@umd.edu

${ }^{2}$ Department of Politics, University of Exeter, Exeter, Devon UK EX4 4SB, L.Jasny@Exeter.ac.uk
} 


\section{Introduction}

Since Donald Trump’s Inauguration, large-scale protest events have taken place around the US, with many of the biggest events being held in Washington, DC. People have marched for a diversity of progressive issues including women's rights, climate change, gun violence, and the Administration's immigration policies. ${ }^{3}$ At this point, the movement to challenge the Trump Administration and its policies—what has come to be known as the Resistance-has become a cycle of contention that is "comparable to the one that Americans experienced during the period of Civil Rights and the movement against Vietnam War [sic]” (Tarrow and Meyer In Press:3).

Although research has looked at differential participation in protest and persistence (see particularly Barkan, Cohn, and Whitaker 1995; Downton and Wehr 1997; Saunders et al. 2012; Verhulst and Walgrave 2009), scholars have yet to look at the patterns among those who turn out repeatedly during one cycle of contention comparing them to less engaged participants (for an overview of cycles of contention, see Tarrow 1998:9). This paper, accordingly, explores the patterns among the protest participants who have come out to multiple protest events to understand what explains persistence in the Resistance. It is broken down into three sections. First, we review the literature on mobilization that aims to understand differential recruitment and participation, paying particular attention to those scholars who have disaggregated protest participants based on their experiences. Second, we explain how the unique dataset of protest participants that we utilize in this paper was collected and the methods that we used to analyze it. Third, we present our findings on how to understand persistence in the Resistance. We conclude by highlighting the ways that our findings contribute to a more general conversation about how to understand differential participation.

\footnotetext{
${ }^{3}$ This list is not meant to be exhaustive.
} 


\section{Studying Differential Recruitment and Differential Participation}

To understand the growth of social movements, extensive research has focused on mobilization processes and how individuals come to be involved in varying forms of collective action (See e.g. Fisher and McInerney 2012; Klandermans et al. 2014; Klandermans and Oegema 1987; Lim 2008; McAdam 1986; Munson 2010). Specifically, research has aimed to understand what explains differential recruitment—who mobilizes to participate—as well as differential participation-who participates more-in social protest. Across this research, most studies focus specifically on the role of structural availability via social ties, biographical availability, and political engagement to explain protest participation (See particularly Klandermans and Oegema 1987; Saunders et al. 2012; Schussman and Soule 2005; Verhulst and Walgrave 2009; see also Wahlström and Wennerhag 2014). In the pages that follow, we review these strands of research, focusing particularly on how research has understood persistence in protest.

\section{Understanding Differential Recruitment}

The role of social networks in facilitating participation in collective action has been a central focus of social movements research on participation in collective action (Bearman and Everett 1993; David B. Tindall 2015; Gould 1991; Jasper and Poulsen 1995; Kim and Bearman 1997;

Kitts 2000; Loveman 1998; Marwell, Oliver, and Prahl 1988; McAdam 1986; Oberschall 1973; Oegema and Klandermans 1994; Tilly 1978). To understand the specific role that social networks play in protest, scholars have explored how different types of social ties assist in social movement recruitment (Diani and McAdam 2003; Heaney and Rojas 2015; McAdam and Paulsen 1993; but see Jasper and Poulsen 1995; Zald and McCarthy 1987), which some studies 
have called "structural availability" (see particularly Saunders et al. 2012; Schussman and Soule 2005).

Much attention has been paid to how personal ties and organizational ties can influence protest participation. One the one hand, scholars have found that social connections to friends, family members, and colleagues can explain protest participation (Klandermans and Oegema 1987; Opp and Gern 1993; see also Rochford 1982). On the other hand, other studies have found that individuals' formal ties to organizations play a more powerful role than personal connections (e.g. Anheier 2003; McAdam and Paulsen 1993; Ohlemacher 1996; Passy 2003). McAdam and Paulson, for example, conclude that organizational ties were more significant than relational channels to personal ties in mobilizing activists to participate in Freedom Summer (McAdam and Paulsen 1993; see also Fernandez and McAdam 1988).

There has also been a growing focus on understanding how mobilization happens in the absence of social ties (see e.g. Jasper and Poulsen 1995; Munson 2010; Zald and McCarthy 1987). In their 1995 study, Jasper and Poulsen find individuals are mobilized through moral shocks, which raise "such a sense of outrage in people that they become inclined toward political action, even in the absence of a network of contacts" (Jasper and Poulsen 1995:498; see also Jasper 1997). McCarthy also compares the differences between two social movements in his study of the Pro-Life and Pro-Choice movements, concluding that the Pro-Choice movement overcame the "infrastructural deficit" of a lack of social ties by mobilizing activists “individually, rather than in preexisting groups” through direct appeals (1987:60). Similarly, Fisher and Boekkooi find that the participants who mobilize to participate in a protest without social ties, tend to hear about events through the various mediated forms of communication on the Internet and tend to come to the protest events alone (Fisher and Boekkooi 2010). 
Other studies look at the biographical availability of individuals to understand their mobilization and commitment to activism (Corrigall-Brown 2011; McAdam 1986). In the words of McAdam, "biographical availability can be defined as the absence of personal constraints that may increase the costs and risks of movement participation, such as full-time employment, marriage, and family responsibilities” (McAdam 1986:70, see also 1989). In their study of individual protest participation, Schussman and Soule integrate biographical availability, political engagement and structural availability to explain differential recruitment in protest participation (Schussman and Soule 2005). These authors find that a combination of factors explains who chooses to participate in protest. In their own words, "people who protest were likely to have been asked to do so, and that those individuals asked to protest tend to belong to organizations, have more education, lack constraints on participation, and are politically engaged” (Schussman and Soule 2005:1099).

\section{Studying Differential Participation}

Like the research on differential recruitment, social ties have also been found to facilitate varying levels of participation in activism, or differential participation. In his somewhat later work, McAdam finds participants in Freedom Summer to be "tied to networks of organizational and personal relationships that helped sustain their activism” (McAdam 1989:758). Similarly, in their study of American Vietnam war resisters in Canada, Hagan and Hansford-Bowles conclude that "continuing contacts with those involved in formative activist experiences" are crucial to retention (Hagan and Hansford-Bowles 2005:246; see also Barkan et al. 1995). Looking at activists involved in the peace movement, Downton and Wehr explain the difference between those who persist in the movement, those who shift their activism to other movements, and those 
who drop out of activism altogether (Downton and Wehr 1997; see also Klandermans 1997).

The authors find that social ties and changes in social ties helped to explain why some members of their sample shifted and others dropped out. Similarly, in their study of canvassers, Fisher and McInerney find that "canvassers who came to the job through their social ties were less likely to be working for the organization a year later than those who came as self-starters” (Fisher and McInerney 2012:123).

The small number of studies that look specifically at differential participation in protest builds directly on this more general research and, like the research on differential recruitment (see particularly Schussman and Soule 2005), these studies also look at the role of structural availability, biographical availability, and political engagement. Most of this research compares data collected from a set of demonstrations to understand different levels of participation. In their 2009 paper, for example, Verhulst and Walgrave compare data collected from 18 demonstrations in eight countries (Verhulst and Walgrave 2009). More recently, Saunders and colleagues analyzed a cross-national dataset of protest participants from seven European countries that were collected in 2009-2010 (Saunders et al. 2012). In both cases, the studies analyze data collected from protest events in numerous locations that focus on a range of issues.

Verhulst and Walgrave specifically aim to understand what explains first-timership for the individuals in their sample. They conclude that age, motivation, and non-organizational mobilization "appear to be consistent and robust predictors of first-timership" (Verhulst and Walgrave 2009:455). Consequently, the more experienced participants in this study were found to be older, and more connected to organizations; they tended to be members of an organization that organized the protest events and to have heard about the event through organizational channels, which they refer to as "closed" mobilization channels. 
Saunders and colleagues also look at differential participation in protest. In their case, the authors disaggregate protest experience further into four categories: Novices, Returners, Repeaters, and Stalwarts (Saunders et al. 2012). Like the Verhulst and Walgrave paper, the authors find that being of a "biographically available "age distinguishes novices from repeaters (Saunders et al. 2012:274). The authors also note that stalwarts—-the most engaged protest participants who report attending 6 or more protests in the past 12 months-are the most politically engaged of all protest participants. In other words, people who participated in many protests over the past year also reported engaging in a range of other forms of political action. Also like the previous study (Verhulst and Walgrave 2009), Saunders and colleagues look at the mobilization channels through which participants heard about the protest events. The authors conclude that the most experienced protesters were also the most likely to have heard about protests via organizational "closed” communication channels (see also Klandermans et al. 2014).

In contrast to this limited research on differential participation, which compares data collected from international data sets of protest events (Saunders et al. 2012:268-71; Verhulst and Walgrave 2009:464-69), this paper presents data collected from six protest-events that all took place during the same cycle of contention of the Resistance in the same city: Washington, DC. In the pages that follow, we begin by describing the protests studied and the methods employed to collect our data. Then, we present findings from our analysis to understand patterns of differential participation in the Resistance.

\section{Studying Protest Events in the Resistance}

This paper presents data collected from participants at six of the largest events that took place since the Resistance began on the day of the inauguration of Donald Trump (For an overview, 
see Meyer and Tarrow 2018; Dana R. Fisher 2018): the March for Science, the People’s Climate March, the March for Racial Justice, the 2018 Women’s March, the March for Our Lives, and the Families Belong Together Event. Data were also collected at the 2017 Women’s March on Washington, DC but, as we discuss in more detail in the data and methods section of this paper, because this paper specifically looks at persistence in the Resistance, data from this first event in the cycle of contention is not included. Together, the responses to the surveys include data from 1,399 participants who were randomly selected from throughout the crowds. All of the data presented in this paper were collected by surveying protesters using a methodology that is consistent with previous research on large-scale protest events (For a summary of the methodology, see Fisher et al. 2005; Heaney and Rojas 2015). Using data collected from field notes, media accounts, and materials from the organizations involved with the protests studied, we provide a brief summary of the six events.

\section{The March for Science}

The March for Science began with a "throwaway line on Reddit”(Guarino 2017). Its aim was "to defend the role of science in policy and society." 4 Although it was originally proposed on social media, the March took on a number of professional scientific associations as its partners, including the American Association for the Advancement of Science (AAAS) and the American Sociological Association. ${ }^{5}$ While many scientists supported and participated in the march, some did not participate because they viewed it as partisan (see Akpan et al. 2017). Satellite marches took place around the world on the same day as the flagship event in DC, which was held on Earth Day 2017-April 22, 2017. An estimated 100,000 people participated in the event in

\footnotetext{
4 https://www.marchforscience.com/

${ }^{5}$ For a full list, see for a full list, see https://www.marchforscience.com/partners (Accessed 20 June 2018).
} 
Washington, DC in the rain. The event involved a rally with speeches, which were headlined by Bill Nye "the science guy."

A twelve-member research team entered the staging area around the Washington Monument through an entrance designated by the organizers. March participants were sampled throughout the morning and early afternoon of the $22^{\text {nd }}$ as they listened to speeches about the importance of science. Researchers completed 212 surveys with a refusal rate of $6 \%$. Analysis are based on the 199 usable surveys (13 were lost due to technical problems in the rain).

People’s Climate March 2017

Exactly a week after the March for Science, the People’s Climate March was held on 29 April 2017. This event in Washington, DC was a follow-up to the first People’s Climate March, which was held in New York City three years earlier on the Sunday before the United Nations hosted talks on the issue of climate change. Although this march was unique in that it was connected to a broader effort to draw attention to the issue of climate change in the US and was not a direct response to the Trump Administration and its policies, participants had a lot to protest by late April. Participants marched to express their concerns about the environmental agenda of the Trump Administration, particularly as the President had signed an executive order in March rescinding the Clean Power Plan ${ }^{6}$ and was threatening to pull out of the Paris Agreement on climate change, which he formally did in June (Fandos 2017). Like the previous marches in this cycle of contention, as well as the 2014 People's Climate March, this event coincided with over 370 coordinated protest events. ${ }^{7}$ Protesters in Washington, DC marched to the White House and

\footnotetext{
6 The Clean Power Plan was designed to regulate the emissions of utilities in the US for details, see https://ballotpedia.org/Clean_Power_Plan_political_timeline (Accessed 8 November 2017).

${ }^{7}$ https://pcm2017.wpengine.com/ (Accessed 7 December 2017)
} 
surrounded it to show that the world was watching as President Trump passed his $100^{\text {th }}$ day in office.

An estimated 200,000 people participated in the PCM in Washington, DC on an unseasonably hot and sunny April day where temperatures reached almost 90 degrees (R. Meyer 2017). A ten-member research team entered the crowd in the designated areas around the National Mall. ${ }^{8}$ March participants were sampled throughout the morning and early afternoon as they lined up to march. Researchers completed 348 surveys with a refusal rate of $11 \%$.

\section{March for Racial Justice}

Like the March for Science, the March for Racial Justice was also initiated by a less professionalized group. In contrast to the other marches with similar origination stories, however, the March for Racial Justice did not end up being coordinated by a broad national committee of seasoned activists nor did it connect with a broad coalition of national groups as organizational partners. On September 30, 2017, the March for Racial Justice (M4RJ) was held in Lincoln Park near Capitol Hill. The protest was planned in June after a police officer was acquitted of all charges related to killing Philando Castile (Stein 2017). After the President's response to the killing of a peaceful protester and the injury of 19 others by a white supremacist in Charlotte, VA in August and his September critiques of NFL athletes who had taken a knee during the national anthem to show their concern for police brutality and their desire for racial justice in America, many expected the march to gain additional support. The march was scheduled to take place on the same day as the March for Black Women a few blocks from the staging area of the March for Racial Justice (Chason 2017). After separate rallies took place, the

\footnotetext{
${ }^{8}$ See map at http://pcm2017.wpengine.com/logistics/\#map (Accessed 7 December 2017).
} 
two groups converged and marched together toward the Capitol and the Department of Justice, ending at the National Mall. A number of concurrent events were scheduled to take place around the country (Baumgaertner 2017).

Due, in part, to its lack of institutional support, turnout was much lower than previous marches in Washington, DC. An estimated 10,000 people participated in the march, which included people from both rallies. A fourteen-member research team entered the crowd in the designated areas around Lincoln Park. Participants were sampled throughout the morning and early afternoon during the rally. Researchers completed 187 surveys with a refusal rate of 17\%.

\section{Women’s March 2018}

Although the national organization that coordinated the 2017 march—The Women’s March, Inc.- - decided to celebrate the one-year anniversary of the March with a rally in Las Vegas, Nevada in January 2018 (Savransky 2018), many of the organizers of the sister marches that took place around the country in 2017, along with the newer group March On and branches of Indivisible, wanted to commemorate the anniversary with another march. After some tense interactions among groups involved in the 2017 Women’s March (For a discussion, see Stockman 2018), the 2018 Women’s March was held on the weekend of the one year anniversary (20-21 January 2018). Events took place in 407 locations around the US and turned out about two million people (Chenoweth and Pressman 2018b).

The march in Washington, DC in 2018 was organized by March Forward Virginia, "the state-level organizers for the 2017 Women’s March.”9 The event was originally arranged to showcase the numerous women's successes in Virginia in the year since the first Women’s

\footnotetext{
${ }^{9}$ For details, see https://www.marchdc.com/qa/ (Accessed 17 August 2018).
} 
March. However, since the federal government shutdown the night before, many Democratic Party leaders ended up staying in Washington, attending the march and speaking at the rally (Chandler and Heim 2018). An estimated 75,000 people participated in the 2018 Women's March in Washington, DC. A six-member research team entered the crowd at the various entrances to the reflecting pool and steps of the Lincoln Memorial and sampled march participants throughout the morning and early afternoon of the $20^{\text {th }}$ while the rally took place. Researchers completed 205 surveys with a refusal rate of $8 \%$

\section{March for Our Lives}

In contrast to these other marches that were called for by adults, high school students who had survived a school shooting in Parkland, Florida called for the March for Our Lives. With the help of some well-resourced benefactors, including Oprah Winfrey and George Clooney, the survivors organized a rally in D.C. on 24 March, a mere six weeks after the school shooting on February $14^{\text {th }}$. The event included speeches by survivors of gun violence and performances by musicians including pop stars Demi Lovato and Ariana Grande. ${ }^{10}$ The march in Washington, DC coincided with 763 sibling marches around the country (Bond, Chenoweth, and Pressman 2018). Organizers estimate that 800,000 people attended the event in DC (Bond et al. 2018), which was the main march. A six-member research team entered the crowd at the various entrances on Pennsylvania Avenue and sampled participants throughout the morning and early afternoon of the $24^{\text {th }}$ while the rally/concert took place. Researchers completed 256 surveys with a refusal rate of $7 \%$.

\footnotetext{
${ }^{10}$ For details, see https://www.thecut.com/2018/03/march-for-our-lives-celebrities-performers-speakers.html (accessed 20 August 2018).
} 


\section{Families Belong Together}

Unlike the other marches that were organized months ahead of time, the Families Belong Together event was organized in 12 days to protest the Trump Administration’s family separation policy that involved children being separated from their parents and held for prosecution. The event was led by a diverse coalitions of over 100 organizations, including MoveOn, the American Civil Liberties Union, the National Domestic Workers Alliance and the Leadership Conference on Civil and Human Rights. ${ }^{11}$ The event turned out an estimated 35,000 people in Washington, DC and coincided with at least 737 sibling marches that were held around the country. Around the country, the event turned out around 450,000 people at these events to protest the Trump administration's separation of children from their parents (Chenoweth and Pressman 2018a). A four-member research team entered the crowd at the various entrances to Lafayette Square and sampled rally participants throughout the morning and early afternoon of the $30^{\text {th }}$ while the rally took place. Researchers completed 201 surveys with a refusal rate of $9 \%$.

Table 1 presents the reported attendance at the six marches compared in this paper, the number of survey participants, and the response rates for each of the protests.

\section{TABLE 1 ABOUT HERE}

\section{Data and Methods}

Participants at all six events were selected using a sampling methodology consistent with other studies of street demonstrations in the U.S. and abroad, which uses a field approximation of random selection at the march (Bédoyan, Aelst, and Walgrave 2004; D. R. Fisher et al. 2005; Heaney and Rojas 2015). Snaking through the crowd as people gathered, researchers "counted

\footnotetext{
${ }^{11}$ For a list, see https://act.moveon.org/survey/families-belong-together-partners/?source=families (accessed 20 August 2018).
} 
off” protesters while participants were lining up and listening to speeches, selecting every fifth person as determined by researchers working in a particular section to participate. This method avoids the potential of selection bias by preventing researchers from selecting only “approachable peers” (Walgrave and Verhulst 2011; Walgrave, Wouters, and Ketelaars 2016). Given the large size of the crowds and the labor-intensive nature of the survey methodology, the samples presented here represent small, randomized portions of the overall participant populations at each demonstration. The survey was designed to be short and non-invasive, so as to encourage the highest level of participation possible and facilitate data collection in the field: it took about 10 minutes for participants to complete it. ${ }^{12}$

All data were collected in accordance with the University of Maryland policies instituted by their Institutional Review Board (Protocol \# 999342-1). As such, only individuals over the age of 18 were eligible to participate in the study. It is worth noting that the refusal rates noted above are consistent with other studies that use this methodology and are substantially lower than those studies that rely on mailed back questionnaires, which can suffer from delayed refusal bias (Walgrave and Verhulst 2011; Walgrave, Wouters, and Ketelaars 2016).

\section{Operationalization of Dependent Variable}

To understand persistence in the Resistance, we run models on two separate dependent variables. The first dependent variable builds directly off of the literature on differential participation reviewed above and specifically looks at the differentiation of participants by their overall previous participation (e.g. Saunders et al. 2012; Verhulst and Walgrave 2009). For this first set of analyses, we look at responses to a question that asks: "How many protests and/or

\footnotetext{
${ }^{12}$ Survey instrument is posted at www.drfisher.umd.edu/Protest.html
} 
demonstrations have you attended in the past five years?” Data were coded into three categories: first time ever participating in a protest, first time in the last five years, and those who report participating in more than one event in the past five years (not including the event where they were surveyed). The two later categories can include any other marches prior to the event where the respondent was surveyed; responses to this question do not necessarily include participation in a demonstration that is part of the Resistance. It is worth highlighting that this operationalization is a combination of the ways that the previous research has looked at differential participation. ${ }^{13}$ The percentage of respondents surveyed at each march who placed themselves into each category is presented in the left-hand side of Figure 1. The marches are ordered in the plot and listed in the legend in temporal order. We see that the proportion of firsttimers at these marches falls at each march as the cycle of contention progresses, with the one exception of the March for Our Lives (for a discussion of turnout at the March for Our Lives, see Dana R Fisher 2018). This plot also clearly shows that the vast majority of respondents overall had participated in more than one event in the past five years.

The second dependent variable, in contrast, specifically looks at persistence in the Resistance. We asked respondents about their attendance at all of the large-scale marches since and including the 2017 Women’s March, which took place the day after the inauguration and has been called the trigger of the Resistance (Meyer and Tarrow 2018:1). The plot on the right-hand side of Figure 1 displays, for each march in temporal order, what percentage of respondents had attended the previous marches in this cycle of contention. Those surveyed at the March for

\footnotetext{
${ }^{13}$ In their study of differential participation in protest, Saunders and colleagues define novices as people who have never before protested, returners as people who have participated 1-5 times ever, and repeaters and stalwarts are both operationalized as having participated in 6 or more protests ever (Saunders et al. 2012:269). In contrast, Verhulst and Walgrave operationalize "first-timership" as people who report that a demonstration is the first time they have ever participated in a protest AND as the first time in the past 5 years that they have participated in a protest (Verhulst and Walgrave 2009:469-70).
} 
Science were asked about their attendance at the 2017 Women's March; those surveyed at the People's Climate March were asked whether or not they had attended either of the previous two marches, and so on. ${ }^{14}$ We see that $66 \%$ of those surveyed at the March for Science- - the second large-scale protest in this cycle of contention—reported having attended the 2017 Women's March. In turn, respondents at the People's Climate March were asked both about the Women's March in 2017 and the March for Science. 25\% of respondents at the People’s Climate March reported attending both previous marches (the 2017 Women’s March and the March for Science), $54 \%$ said that they were at one of the previous marches, and $21 \%$ responded that they had attended neither. We cannot directly compare these numbers as, because fewer events had happened at the time of the March for Science, those respondents were constrained to either 0 or 1, whereas only respondents at the Families Belong Together March, which took pace in June 2018, could potentially have attended six previous events.

\section{FIGURE 1 ABOUT HERE}

Because the possible marches respondents could have attended increased at each march, it is not appropriate to use the raw numbers of marches attended as a dependent variable. Additionally, simply using the percentage of the events the respondent could have attended is problematic because of the assumptions of linear regression. Instead, we estimate the underlying rate of participation using a Bayesian transformation of these counts. The dependent variable we model is the posterior mean of a Jeffrey's prior and the binomial distribution of the number of marches attended given the number the respondent could possibly attend (for references on this transformation, see Rubin and Schenker 1987; for information on the Jeffrey's prior, see Lunn et

\footnotetext{
${ }^{14}$ Data were also collected at the 2017 Women's March. Since this paper specifically looks at persistence in the Resistance and the 2017 event was the first march in this cycle of contention, those data are not included in this analysis (For an analysis and discussion of the 2017 Women's March data, see Dana R. Fisher 2018; Fisher, Dow, and Ray 2017).
} 
al. 2012; for similar application using count data, see Hadden and Jasny 2017). Our two dependent variables measure slightly different versions of previous behavior and are, understandingly, highly significantly correlated with a Pearson correlation of .62 ( $<<2 \mathrm{e}-16)$.

\section{Operationalization of Independent Variables.}

Our analysis includes measures similar to those used in the recent research on differential recruitment and differential participation (Saunders et al. 2012; Schussman and Soule 2005; Verhulst and Walgrave 2009). In particular, we include variables to measure biographical availability, structural availability, and political participation. In addition to these three categories, we also add a fourth category: issue motivations.

Biographical availability contains a continuous variable for Age and a scale for Education (1 is "Did not finish high school to 5 "Graduate or Professional Degree). We include binary measures for gender (Female, Male) and race (Non-White, White), and whether or not the respondent was considered unemployed. Each of these three variables were dichotomized from broader information. In the case of gender, too few respondents gave an alternative category to be included in the regression. The initial survey also asked about a number of ethnic categories, however similarly, too few respondents across the marches were in each separate category so they were combined into a 'non-white' category (for a full discussion, see Fisher, Jasny, and Dow Under Review: appendix). Our operationalization of unemployed follows Saunders et al. (2012), who include those who categorized themselves as a student, unemployed, retired or a stay-at-home parent in their variable.

For Structural Availability, we include a series of variables that measure organizational and personal ties. Specifically, we include binary variables for: whether the respondent was a 
member of a group that was part of the organizing coalition for the march; whether the respondent came to the event with other organizational members; a collapsed variable for whether they came with friends, family, or colleagues; and whether they reported coming to the event alone. Our final variable for this category is a scale capturing how the respondent heard about the event. It is ranked in a manner consistent with the way the literature has termed open (1) to closed (4) channels (see particularly Saunders et al. 2012; Verhulst and Walgrave 2009).

For Political Participation, we include a series of binary variables. Respondents were asked to tick which of a list of 10 civic and/or political activities they had participated in over the past 12 months. We also include a scale of Political View (1 is "Very Left" to 7 "Very Right).

We also added a series of binary variables to reflect what issues motivated participants to join the demonstration where they were surveyed. This addition builds on recent research that finds participants in demonstrations in the Resistance to be motivated by a range of issues to participate (Fisher et al. Under Review; see also Fisher, Dow, and Ray 2017). Respondents were asked to tick off from a list of 14 issues what issue(s) motivated them to turnout at the specific event where they were surveyed. Descriptive results and t-tests (for continuous variables) and chi-squared tests (for binary variables) comparing each event to the total are shown in Table 2.

\section{TABLE 2 ABOUT HERE}

We see from the description of the variables included that there are many differences in participants across the different marches. For example, the participants at the March For Our Lives were significantly less likely to have participated in other forms of political engagement. We see that a larger proportion of the participants at the March for Science were white, and a larger proportion of the participants at the March for Racial Justice identified as non-white. In addition, significantly more men attended the March for Science and the People’s Climate 
March, but significantly fewer participants were male at the Women’s March in 2018. We also see that issues related to the particular event's themes were more likely to fluctuate based on the protest where data were collected.

\section{Results}

We use two separate regression techniques - a multinomial logistic regression for analyzing differential participation (our first dependent variable) and a linear regression for the persistence across this cycle of contention (our second dependent variable). The multinomial is appropriate for the first dependent variable as the differences in protest participation categories are not ordinal. For the second set of analysis, because of our Bayesian transformation, the dependent variable capturing the log-odds that a participant is likely to engage in an event during the current cycle of contention is appropriate to a linear model (see e.g. Hadden and Jasny 2017). Given the differences in some of the descriptives by event, we include variables for each different event in the models presented. ${ }^{15}$ The results are presented in Table 3.

\section{TABLE 3 ABOUT HERE}

\section{Differential Participation Model}

From the separate intercepts for the different events, we see that first timers (the reference category for the multinomial model of differential participation) were more likely to attend the March for Science and the People’s Climate March than those who report having attended more than one other protest event in the past five years. We see no difference among march attendance

\footnotetext{
${ }^{15}$ Separate models were run with interaction effects by Event for each of the independent variables. Since, none of these additions improved the BIC value, we present the reduced models without any interaction effects in this paper.
} 
for first timers relative to those who reported attending one other demonstration in the past five years.

The results of the persistence model also provide some support for the findings from the previous research. We turn first to our biographical availability variables. Compared to those who are first timers, those with previous experience at both levels are more likely to be highly educated and to be unemployed. These findings are consistent with the work of Saunders and colleagues (2012). Although we find that those who have attended one event in the past five years are slightly older than first timers, we do not see the same effect for those who report attending more than one protest event in the last five years. Additionally, those who have attended more than one event in the last five years are also less likely to be white.

In contrast to previous studies, we do not find any support for structural availability. Neither organizational membership, nor coming to the events with members of an organization were statistically significant. We also find no support for the findings from the previous studies that people with higher levels of protest participation are more likely to hear about a demonstration through closed communication channels.

Regarding political participation, we find that those respondents who had attended one other event in the past five years were more likely than first timers to have participated in direct action, but less likely to have worked for a political party. These findings provide evidence that events in this cycle of contention were mobilizing newcomers to participate in protest who were already engaging in institutional politics $(17 \%$ of the total sample stated they had worked for a political party). Moreover, when we compare those who report participating in more than one event in the past five years to first timers, we find they were more likely to have engaged in a range of political activities. Specifically, they are more likely to have contacted their elected 
officials, contacted the media, signed a petition, and participated in direct action. They were less likely to have worked for a political party or to have engaged in political discussion online. Moreover, those who have attended more than one event in the last five years are more likely to identify more towards the liberal end of the political spectrum, which is consistent with the research by Saunders and colleagues (2012).

Finally, in the multinomial model we see strong differences in issue motivation between first timers and those who had attended one or more other events in the last five years. In particular, all of those who reported any previous participation in protest were more likely to state they were motivated to participated by the issues of Equality and Politics compared to first timers. Those with any previous protest experience were less likely to be motivated by the issue of Racial Justice than first timers. Also, those who reported attending more than one event in the past five years were also less likely to be motivated by the issue of Social Welfare.

\section{Persistence Model}

Turning next to the persistence model, which predicts the underlying log-odds of attending additional protest events during the current cycle of contention, we find few characteristics that are statistically significant and some in direct contradiction to the previous model, as well as the literature on differential participation. While the attendees at the March for Science and the People's Climate March were less likely to have reported attending previous protest events prior to being surveyed at a demonstration, they are more likely to have higher log-odds of attending 
other events in this cycle of contention. In other words, they are more likely to have participated in the previous marches of the Resistance.

None of the biographical availability variables nor the structural availability variables were significant in predicting persistence. When looking at political participation, only contacting an elected official in the past year was associated with increased log-odds of participating in previous events. It is worth highlighting that this measure is the sole independent variable that predicts both previous protest participation generally (our first dependent variable), as well as persistence in this specific cycle of contention (our second dependent variable).

Finally, the results of the persistence model also show that the issues motivating individuals with higher odds of returning to events in the Resistance are very different than our findings regarding differential participation. Individuals motivated by Reproductive Rights were significantly more likely to have higher log-odds of recurring participation. At the same time, those motivated by the general issue of politics were significantly less likely to have participated in other events in this cycle.

\section{Conclusion}

Overall, by looking at data collected from multiple protest-events in one city during one cycle of contention, we learn more about both differential participation, as well as persistence. Like the previous research predicts, we find some support for biographical availability explaining differential participation (Saunders et al. 2012; Verhulst and Walgrave 2009). Moreover, like the study by Saunders and colleagues (2012; see also Schussman and Soule 2005), we also find that political participation is associated with more protest participation. In contrast to these previous studies, however, we do not find that any measure of structural availability predicts higher levels 
of participation. In other words, social ties explain neither repeat participation in protest events, nor persistence in this specific cycle of contention. Future research must explore the degree to which these findings are unique to the dataset collected from participants in multiple protests of the Resistance.

When we look specifically at the variables that explain persistence in the Resistance, our results are surprising. In particular, we find that, in contrast to all of the variables that explained differential participation, only contacting an elected official in the past year is a significant predictor of persistence. This finding provides evidence that people who are turning out to protest the Trump Administration and its policies are participating in institutional politics in a particular way.

In addition, we find that the issue of Reproductive Rights motivated people to turn out again-and-again. This finding in some ways replicates what other studies of protests in the Resistance have found: women and women’s issues have been a major focus of the current cycle of contention ever since the Women’s March (Fisher et al. 2017; Meyer and Tarrow 2018; Putnam and Skocpol 2018). ${ }^{16}$ At the same time, the issue of Politics was negatively associated with persistence. In other words, although some people came out to participate in demonstrations because they were motivated by Politics and the political system in America, they were less likely to come out again-and-again. It is very likely that the importance of these issues as motivations to protest and persist may be unique to this cycle of contention and the product of the current political climate in the United States.

Future research must continue to look at differential participation and persistence in protests that are part of one cycle of contention. Through such research, we will be able to learn

\footnotetext{
${ }^{16}$ It is worth nothing that this finding for Reproductive Rights holds even if the Women's March 2018 observations are removed from the data set.
} 
if these findings about those who are persisting in the Resistance are unique to this particular cycle of contention. 


\section{References:}

Akpan, Nsikan, Andrew Wagner, Kristin Hugo, and Julia Griffin. 2017. "Why These People Are Joining — or Skipping — the March for Science.” PBS NewsHour. Retrieved July 11, 2018 (https://www.pbs.org/newshour/science/people-joining-skipping-march-science).

Anheier, Helmut. 2003. "Movement Development and Organizational Networks: The Role of 'Single Members’ In the German Nazi Party, 1925-30.” Pp. 49-72 in Social Movements and Networks, Diani and McAdam, Editors. Oxford University Press.

Barkan, Steven E., Steven F. Cohn, and William H. Whitaker. 1995. “Beyond Recruitment: Predictors of Differential Participation in a National Antihunger Organization.” Sociological Forum 10(1):113-34.

Baumgaertner, Emily. 2017. “Marches for Racial Justice and Black Women Converge in Washington.” The New York Times, September 30.

Bearman, Peter S. and Kevin D. Everett. 1993. “The Structure of Social Protest, 1961-1983.” Social Networks 15(2):171-200.

Bédoyan, Isabelle, Peter Aelst, and Stefaan Walgrave. 2004. "Limitations and Possibilities of Transnational Mobilization: The Case of Eu Summit Protesters in Brussels, 2001.” Mobilization: An International Quarterly 9(1):39-54.

Bond, Erica, Erica Chenoweth, and Jeremy Pressman. 2018. "Did You Attend the March for Our Lives? Here's What It Looked like Nationwide.” Washington Post, April 13.

Chandler, Michael Alison and Joe Heim. 2018. “Protesters Gather for a Second Women’s March in Nation's Capital.” Washington Post. Retrieved August 17, 2018 (https://www.washingtonpost.com/local/protesters-gather-for-a-second-womens-marchin-nations-capital/2018/01/20/c641bf16-fdef-11e7-ad8c-ecbb62019393_story.html).

Chason, Rachel. 2017. “'Let the Black Women Lead’: Marches Converge on D.C. to Highlight Racial Injustice.” Washington Post, September 30.

Chenoweth, Erica and Jeremy Pressman. 2018a. "Millions of Protesters Turned out in June More than in Any Month since Trump’s Inauguration.” The Washington Post, August 31.

Chenoweth, Erica and Jeremy Pressman. 2018b. “The Women’s March Could Change Politics like the Tea Party Did | Erica Chenoweth and Jeremy Pressman.” The Guardian, January 31.

Corrigall-Brown, Catherine. 2011. Patterns of Protest: Trajectories of Participation in Social Movements. Stanford University Press.

David B. Tindall. 2015. "Networks as Constraints and Opportunities.” P. chapter 14 in Oxford Handbooks of Social Movements Edited by della Porta and Diani. Oxford University Press. 
Diani, Mario and Doug McAdam, eds. 2003. Social Movements and Networks: Relational Approaches to Collective Action. Oxford, New York: Oxford University Press.

Downton, James and Paul Wehr. 1997. The Persistent Activist: How Peace Commitment Develops And Survives. Boulder, Colo: Westview Press.

Fandos, Nicholas. 2017. “Climate March Draws Thousands of Protesters Alarmed by Trump’s Environmental Agenda.” The New York Times, April 29.

Fernandez, Roberto M. and Doug McAdam. 1988. “Social Networks and Social Movements: Multiorganizational Fields and Recruitment to Mississippi Freedom Summer.” Sociological Forum 3(3):357-82.

Fisher, Dana R. 2018. “American Resistance.” American Resistance Book. Retrieved August 17, 2018 (https://wordpress.com/view/americanresistancebook.com).

Fisher, Dana R. 2018. “Here’s Who Actually Attended the March for Our Lives. (No, It Wasn’t Mostly Young People.).” The Washington Post, March 28.

Fisher, Dana R. and Marije Boekkooi. 2010. "Mobilizing Friends and Strangers: Understanding the Role of the Internet in the Step It Up Day of Action.” Information, Communication \& Society 13(2):193-208.

Fisher, Dana R., Dawn M. Dow, and Rashawn Ray. 2017. "Intersectionality Takes It to the Streets: Mobilizing across Diverse Interests for the Women’s March.” Science Advances 3(9):eaao1390.

Fisher, Dana R., Lorien Jasny, and Dawn M. Dow. Under Review. "Why Are We Here? Patterns of Intersectional Motivations Across the Resistance.”

Fisher, Dana R. and Paul-Brian McInerney. 2012. “The Limits of Networks in Social Movement Retention: On Canvassers and Their Careers.” Mobilization: An International Quarterly 17(2):109-28.

Fisher, Dana R., Kevin Stanley, David Berman, and Gina Neff. 2005. "How Do Organizations Matter? Mobilization and Support for Participants at Five Globalization Protests.” Social Problems 52(1):102-21.

Gould, Roger V. 1991. "Multiple Networks and Mobilization in the Paris Commune, 1871.” American Sociological Review 56(6):716-29.

Guarino, Ben. 2017. “The March for Science Began with This Person’s ‘Throwaway Line’ on Reddit.” Washington Post, April 21.

Hadden, Jennifer and Lorien Jasny. 2017. “The Power of Peers: How Transnational Advocacy Networks Shape NGO Strategies on Climate Change.” British Journal of Political Science 1-23. 
Hagan, John and Suzanne Hansford-Bowles. 2005. "From Resistance to Activism: The Emergence and Persistence of Activism among American Vietnam War Resisters in Canada.” Social Movement Studies 4(3):231-59.

Heaney, Michael T. and Fabio Rojas. 2015. Party in the Street: The Antiwar Movement and the Democratic Party after 9/11. Cambridge University Press.

Jasper, James M. 1997. The Art of Moral Protest: Culture, Biography, and Creativity in Social Movements. University of Chicago Press.

Jasper, James M. and Jane D. Poulsen. 1995. "Recruiting Strangers and Friends: Moral Shocks and Social Networks in Animal Rights and Anti-Nuclear Protests.” Social Problems 42(4):493-512.

Kim, Hyojoung and Peter S. Bearman. 1997. "The Structure and Dynamics of Movement Participation.” American Sociological Review 62(1):70-93.

Kitts, James. 2000. "Mobilizing in Black Boxes: Social Networks and Participation in Social Movement Organizations.” Mobilization: An International Quarterly 5(2):241-57.

Klandermans, Bert. 1997. The Social Psychology of Protest. Wiley.

Klandermans, Bert and Dirk Oegema. 1987. "Potentials, Networks, Motivations, and Barriers: Steps Towards Participation in Social Movements.” American Sociological Review 52(4):519-31.

Klandermans, Bert, Jacquelien van Stekelenburg, Marie-Louise Damen, Dunya van Troost, and Anouk van Leeuwen. 2014. "Mobilization Without Organization: The Case of Unaffiliated Demonstrators.” European Sociological Review 30(6):702-16.

Lim, Chaeyoon. 2008. “Social Networks and Political Participation: How Do Networks Matter?” Social Forces 87(2):961-82.

Loveman, Mara. 1998. "High-Risk Collective Action: Defending Human Rights in Chile, Uruguay, and Argentina.” American Journal of Sociology 104(2):477-525.

Lunn, David, Chris Jackson, Nicky Best, Andrew Thomas, and David Spiegelhalter. 2012. The BUGS Book: A Practical Introduction to Bayesian Analysis. CRC Press.

Marwell, Gerald, Pamela E. Oliver, and Ralph Prahl. 1988. "Social Networks and Collective Action: A Theory of the Critical Mass. III.” American Journal of Sociology 94(3):50234.

McAdam, Doug. 1986. "Recruitment to High-Risk Activism: The Case of Freedom Summer.” American Journal of Sociology 92(1):64-90.

McAdam, Doug. 1989. “The Biographical Consequences of Activism.” American Sociological Review 54(5):744-60. 
McAdam, Doug and Ronnelle Paulsen. 1993. "Specifying the Relationship Between Social Ties and Activism.” American Journal of Sociology 99(3):640-67.

Meyer, David S. and Sidney Tarrow. 2018. The Resistance: The Dawn of the Anti-Trump Opposition Movement. Oxford University Press, USA.

Meyer, Robinson. 2017. “The Climate March’s Big Tent Strategy Draws a Big Crowd.” The Atlantic, April 30.

Munson, Ziad W. 2010. The Making of Pro-Life Activists: How Social Movement Mobilization Works. University of Chicago Press.

Oberschall, Anthony. 1973. Social Conflict and Social Movements. Pearson Education, Limited.

Oegema, Dirk and Bert Klandermans. 1994. "Why Social Movement Sympathizers Don’t Participate: Erosion and Nonconversion of Support.” American Sociological Review 59(5):703-22.

Ohlemacher, Thomas. 1996. "Bridging People and Protest: Social Relays of Protest Groups against Low-Flying Military Jets in West Germany.” Social Problems 43(2):197-218.

Opp, Karl-Dieter and Christiane Gern. 1993. "Dissident Groups, Personal Networks, and Spontaneous Cooperation: The East German Revolution of 1989.” American Sociological Review 58(5):659-80.

Passy, Florence. 2003. "Social Networks Matter. But How ?” Pp. 21-47 in Social Movements and Networks, Diani and McAdam, Editors. Oxford University Press.

Putnam, Lara and Theda Skocpol. 2018. “Middle America Reboots Democracy.” Democracy Journal.

Rochford, E. Burke. 1982. "Recruitment Strategies, Ideology, and Organization in the Hare Krishna Movement.” Social Problems 29(4):399-410.

Rubin, Donald B. and Nathaniel Schenker. 1987. "Logit-Based Interval Estimation for Binomial Data Using the Jeffreys Prior.” Sociological Methodology 17:131-44.

Saunders, Clare, Maria Grasso, Cristiana Olcese, Emily Rainsford, and Christopher Rootes. 2012. "Explaining Differential Protest Participation: Novices, Returners, Repeaters, and Stalwarts.” Mobilization: An International Quarterly 17(3):263-80.

Savransky, Rebecca. 2018. “Women’s March Organizers to Launch Voter Registration Tour.” The Hill, January 17.

Schussman, Alan and Sarah Anne Soule. 2005. "Process and Protest: Accounting for Individual Protest Participation.” Social Forces 84(2):1083-1108. 
Stein, Perry. 2017. "March for Racial Justice and March for Black Women Will Converge in D.C. This Weekend.” Washington Post, September 28.

Stockman, Farah. 2018. “One Year After Women’s March, More Activism but Less Unity.” The New York Times, January 15.

Tarrow, Sidney. 1998. Power in Movement: Social Movements and Contentious Politics. Cambridge University Press.

Tarrow, Sidney and David S. Meyer. In Press. “The Challenges of the Anti-Trump Movement.” Participation and Conflict.

Tilly, Charles. 1978. From Mobilization to Revolution. Reading, Mass: Addison-Wesley.

Verhulst, Joris and Stefaan Walgrave. 2009. “The First Time Is the Hardest? A Cross-National and Cross-Issue Comparison of First-Time Protest Participants.” Political Behavior 31(3):455-84.

Wahlström, Mattias and Magnus Wennerhag. 2014. “Alone in the Crowd: Lone Protesters in Western European Demonstrations.” International Sociology 29(6):565-583.

Walgrave, Stefaan and Joris Verhulst. 2011. "Selection and Response Bias in Protest Surveys.” Mobilization: An International Quarterly 16(2):203-22.

Walgrave, Stefaan, Ruud Wouters, and Pauline Ketelaars. 2016. "Response Problems in the Protest Survey Design: Evidence from Fifty-One Protest Events in Seven Countries.” Mobilization: An International Quarterly 21(1):83-104.

Zald, M. N. and John D. McCarthy, eds. 1987. "Pro-Life and Pro-Choice Mobilization: Infrastructure Deficits and New Technologies.” Pp. 49-66 in Social Movements in an Organizational Society. Neew Brunswick and London: Transaction Publishers. 
FIGURE 1: Dependent variables used in analysis (a) Percent of respondents at each march who identified in each category of previous participation (b) Number of previous events in the Resistance attended by the percentage of respondents surveyed at each event. Note that March For Science respondents were only given the option of having attended the 2017 Women's March (WM17), thus were constrained to 1 other event, etc.
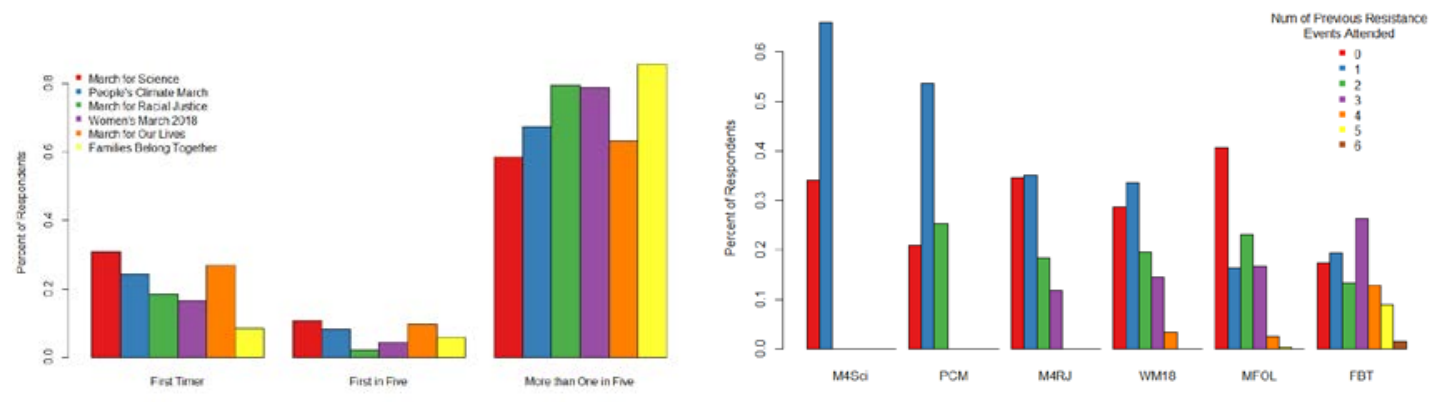

Table 1: Overview of Marches Studied

\begin{tabular}{|l|c|c|c|c|c|c|}
\hline & $\begin{array}{c}\text { March } \\
\text { for } \\
\text { Science }\end{array}$ & $\begin{array}{c}\text { People's } \\
\text { Climate } \\
\text { March }\end{array}$ & $\begin{array}{c}\text { March for } \\
\text { Racial } \\
\text { Justice }\end{array}$ & $\begin{array}{c}\text { Women's } \\
\text { March } \\
\mathbf{2 0 1 8}\end{array}$ & $\begin{array}{c}\text { March } \\
\text { for Our } \\
\text { Lives }\end{array}$ & $\begin{array}{c}\text { Families } \\
\text { Belong } \\
\text { Together }\end{array}$ \\
\hline $\begin{array}{l}\text { Estimated } \\
\text { Attendance }\end{array}$ & 100,000 & 200,000 & 10,000 & 75,000 & 500,000 & 35,000 \\
\hline $\begin{array}{l}\text { Total Completed } \\
\text { Surveys }\end{array}$ & 201 & 351 & 185 & 205 & 256 & 201 \\
\hline Response Rate & $94 \%$ & $89 \%$ & $83 \%$ & $92 \%$ & $93 \%$ & $91 \%$ \\
\hline
\end{tabular}


Table 2: Descriptives

\begin{tabular}{|c|c|c|c|c|c|c|c|c|}
\hline & Variable & Total & M4Sci & PCM & M4RJ & WM18 & MFOL & FBT \\
\hline & $\mathrm{n}$ & 1399 & 201 & 351 & 185 & 205 & 256 & 201 \\
\hline \multirow{2}{*}{$\stackrel{\dot{\vec{\nu}}}{\Delta} \stackrel{\dot{m}}{\nu^{\circ}}$} & Prev Participation & 2.50 & $2.28^{* *}$ & 2.43 & 2.61 & $2.62^{*}$ & $2.36^{*}$ & $2.77^{* * *}$ \\
\hline & Persistence & -0.47 & $0.35^{* * *}$ & $0.07^{* * *}$ & -0.53 & $-0.72^{* *}$ & $-1.14^{* * *}$ & -0.55 \\
\hline \multirow{6}{*}{ 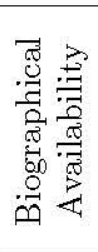 } & Age & 42.62 & 40.32 & 42.65 & $37.81^{* * *}$ & 42.22 & $47.79^{* * *}$ & 43.71 \\
\hline & White & 0.75 & $0.86^{* *}$ & 0.77 & $0.62^{* * *}$ & 0.77 & 0.78 & 0.71 \\
\hline & Male & 0.32 & $0.44^{* *}$ & $0.38^{*}$ & 0.32 & $0.18^{* * *}$ & 0.29 & 0.27 \\
\hline & Political View & 2.32 & 2.50 & 2.38 & 2.24 & 2.22 & 2.44 & $2.10^{* *}$ \\
\hline & Education & 4.94 & $5.30^{* *}$ & 5.08 & 4.86 & $4.14^{* *}$ & $4.10^{* *}$ & 5.06 \\
\hline & Unemployed & 0.30 & 0.30 & 0.32 & 0.34 & 0.31 & 0.26 & 0.28 \\
\hline \multirow{5}{*}{ 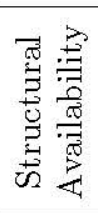 } & Mem of Sponsor Org & 0.24 & 0.2 & $0.37^{* * *}$ & $0.16^{*}$ & $0.17^{*}$ & $0.16^{* *}$ & $0.32^{*}$ \\
\hline & Alone & 0.12 & 0.11 & $0.11^{* * *}$ & $0.11^{*}$ & $0.10^{*}$ & $0.10^{* *}$ & $0.19^{*}$ \\
\hline & Family,Friends & 0.80 & $0.87^{*}$ & $0.74^{*}$ & 0.76 & 0.85 & 0.83 & 0.77 \\
\hline & Org Members & 0.12 & 0.13 & $0.21^{* * *}$ & 0.17 & $0.06^{* *}$ & $0.05^{* * *}$ & $0.06^{*}$ \\
\hline & Open-Closed Scale & 2.19 & 2.08 & $2.59^{* *}$ & 2.36 & 2.24 & $1.17^{* * *}$ & 2.09 \\
\hline \multirow{10}{*}{ 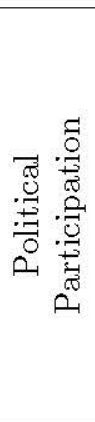 } & Contact Rep & 0.73 & $0.92^{* * *}$ & $0.84^{* * *}$ & $0.65^{*}$ & $0.61^{* * *}$ & $0.61^{* * *}$ & 0.72 \\
\hline & Contact Media & 0.36 & $0.64^{* * *}$ & $0.61^{* * *}$ & $0.28^{*}$ & $0.20^{* * *}$ & $0.17^{* * *}$ & $0.21^{* * *}$ \\
\hline & Petition & 0.81 & $0.89^{*}$ & 0.85 & 0.78 & 0.80 & $0.71^{* * *}$ & 0.85 \\
\hline & Attend Meeting & 0.46 & 0.47 & 0.48 & 0.51 & 0.40 & 0.41 & 0.51 \\
\hline & Work Party & 0.17 & 0.13 & 0.19 & 0.18 & 0.17 & 0.15 & 0.17 \\
\hline & Speech & 0.10 & 0.11 & 0.13 & 0.12 & $0.04^{*}$ & 0.08 & 0.08 \\
\hline & Voted & 0.77 & $0.89^{* * *}$ & 0.80 & 0.75 & $0.68^{* *}$ & $0.66^{* * *}$ & $0.86^{* *}$ \\
\hline & Online Politics & 0.53 & $0.64^{* *}$ & 0.52 & $0.62^{*}$ & 0.49 & $0.39^{* * *}$ & $0.61^{*}$ \\
\hline & Direct Action & 0.35 & 0.33 & $0.43^{* *}$ & 0.42 & 0.28 & $0.22^{* * *}$ & 0.41 \\
\hline & Collected & 0.12 & 0.20 & 0.14 & 0.14 & 0.14 & 0.07 & 0.04 \\
\hline \multirow{14}{*}{ 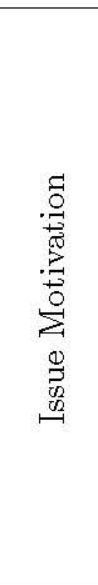 } & Environment & 0.80 & $0.92^{* * *}$ & $0.96^{* * *}$ & $0.22^{* * *}$ & $0.90^{* * *}$ & $0.72^{* *}$ & $0.92^{* * *}$ \\
\hline & Immigration & 0.32 & 0.28 & $0.33^{* * *}$ & $0.57^{* * *}$ & 0.28 & $0.22^{* *}$ & 0.28 \\
\hline & Labor & 0.19 & 0.18 & $0.25^{*}$ & 0.18 & 0.18 & 0.14 & 0.18 \\
\hline & LGBTQ & 0.25 & 0.22 & 0.28 & $0.41^{* * *}$ & 0.21 & $0.17^{* *}$ & 0.22 \\
\hline & Peace & 0.36 & 0.34 & $0.43^{*}$ & 0.42 & 0.34 & $0.27^{* *}$ & 0.34 \\
\hline & Racial Justice & 0.35 & $0.25^{* *}$ & 0.36 & $0.89^{* * *}$ & $0.25^{* *}$ & $0.20^{* * *}$ & $0.25^{* *}$ \\
\hline & Reproduction & 0.28 & 0.32 & 0.28 & 0.23 & 0.31 & 0.25 & 0.32 \\
\hline & Social Welfare & 0.34 & 0.35 & 0.37 & 0.38 & 0.34 & $0.27^{*}$ & 0.35 \\
\hline & Women's Rights & 0.39 & 0.39 & 0.39 & $0.48^{*}$ & 0.39 & $0.31^{*}$ & 0.39 \\
\hline & Police Brutality & 0.30 & $0.21^{* *}$ & 0.29 & $0.79^{* * *}$ & $0.21^{* *}$ & $0.17^{* * *}$ & $0.21^{* *}$ \\
\hline & Trump & 0.50 & 0.52 & 0.55 & 0.44 & 0.51 & $0.41^{* *}$ & 0.52 \\
\hline & Politics & 0.39 & 0.43 & 0.39 & 0.36 & 0.42 & 0.34 & 0.43 \\
\hline & Equality & 0.47 & 0.45 & 0.47 & $0.75^{* * *}$ & 0.44 & $0.35^{* * *}$ & 0.45 \\
\hline & Religion & 0.13 & 0.12 & 0.17 & 0.14 & 0.12 & 0.10 & 0.12 \\
\hline
\end{tabular}

Significance for continuous variables determined by t-test, for dichotomous chi-sq test

${ }^{* * *} p<0.001,{ }^{* *} p<0.01,{ }^{*} p<0.05$ 
Table 3: Model Results

\begin{tabular}{|c|c|c|c|c|}
\hline & & \multicolumn{2}{|c|}{ Previous Participation (Multinomial) } & \multirow[t]{2}{*}{ Persistence Participation } \\
\hline & & 1 in 5 & more than 1 in 5 & \\
\hline & Intercept & $-12.90(4.61)^{* *}$ & $-7.94(3.63)^{*}$ & $-1.87(0.70)^{* *}$ \\
\hline \multirow{5}{*}{ 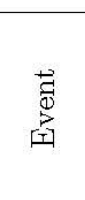 } & March for Science & $-4.34(2.44)$ & $-5.34(2.01)^{* *}$ & $0.98(0.38)^{*}$ \\
\hline & People's Climate March & $-2.45(2.27)$ & $-3.65(1.85)^{*}$ & $0.76(0.36)^{*}$ \\
\hline & March for Racial Justice & $1.65(3.14)$ & $3.04(2.59)$ & $0.65(0.44)$ \\
\hline & March for Our Lives & $-1.02(2.39)$ & $-2.53(2.00)$ & $-0.15(0.40)$ \\
\hline & Families Belong Together & $-0.74(2.63)$ & $-0.80(1.98)$ & $-0.03(0.41)$ \\
\hline \multirow{6}{*}{ 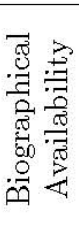 } & Age & $0.08(0.03)^{*}$ & $0.05(0.03)$ & $-0.00(0.01)$ \\
\hline & White & $-2.12(1.21)$ & $-2.02(1.00)^{*}$ & $0.08(0.19)$ \\
\hline & Male & $1.05(0.95)$ & $0.46(0.72)$ & $-0.12(0.16)$ \\
\hline & Political View & $-0.10(0.29)$ & $-0.46(0.23)^{*}$ & $-0.07(0.06)$ \\
\hline & Education & $0.78(0.37)^{*}$ & $0.81(0.30)^{* *}$ & $0.02(0.06)$ \\
\hline & Unemployed & $3.57(1.29)^{* *}$ & $2.61(1.13)^{*}$ & $-0.29(0.17)$ \\
\hline \multirow{5}{*}{ 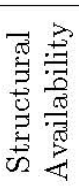 } & Mem of Sponsor Org & $1.56(1.08)$ & $0.96(0.86)$ & $0.29(0.17)$ \\
\hline & Alone & $-3.04(2.67)$ & $-3.00(2.11)$ & $0.29(0.42)$ \\
\hline & Family,Friends, Colleagues & $0.78(1.97)$ & $0.65(1.58)$ & $0.35(0.29)$ \\
\hline & Org Members & $0.75(1.63)$ & $0.49(1.28)$ & $0.04(0.24)$ \\
\hline & Open-Closed Scale & $0.41(0.47)$ & $0.46(0.42)$ & $-0.02(0.07)$ \\
\hline \multirow{10}{*}{ 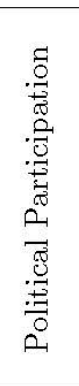 } & Contact Rep & $1.29(1.34)$ & $2.17(0.99)^{*}$ & $0.69(0.27)^{*}$ \\
\hline & Contact Media & $1.67(1.07)$ & $2.04(0.80)^{*}$ & $0.25(0.19)$ \\
\hline & Petition & $3.53(1.85)$ & $2.50(1.13)^{*}$ & $0.18(0.31)$ \\
\hline & Attend Meeting & $-0.51(0.96)$ & $0.05(0.73)$ & $0.00(0.16)$ \\
\hline & Work Party & $-3.18(1.49)^{*}$ & $-3.10(1.30)^{*}$ & $0.00(0.19)$ \\
\hline & Speech & $4.19(2.19)$ & $3.60(1.86)$ & $-0.20(0.25)$ \\
\hline & Voted & $2.09(1.34)$ & $1.64(1.01)$ & $-0.02(0.24)$ \\
\hline & Online Politics & $-1.80(1.03)$ & $-1.94(0.83)^{*}$ & $-0.04(0.18)$ \\
\hline & Direct Action & $5.17(1.78)^{* *}$ & $5.80(1.66)^{* * *}$ & $0.21(0.17)$ \\
\hline & Collected & $-0.14(1.53)$ & $0.13(1.24)$ & $0.28(0.21)$ \\
\hline \multirow{21}{*}{ 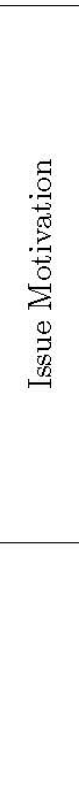 } & Environment & $-0.74(2.18)$ & $1.10(1.93)$ & $0.17(0.30)$ \\
\hline & Immigration & $0.88(1.32)$ & $0.78(0.90)$ & $-0.35(0.24)$ \\
\hline & Labor & $-2.08(1.42)$ & $-1.53(1.07)$ & $0.22(0.24)$ \\
\hline & LGBTQ & $3.05(1.77)$ & $0.22(1.21)$ & $0.05(0.28)$ \\
\hline & Peace & $-0.96(1.12)$ & $-0.08(0.81)$ & $-0.21(0.20)$ \\
\hline & Racial Justice & $-4.54(1.83)^{*}$ & $-2.83(1.26)^{*}$ & $-0.33(0.26)$ \\
\hline & Reproductive Rights & $-2.04(1.60)$ & $0.12(0.95)$ & $0.68(0.26)^{* *}$ \\
\hline & Social Welfare & $-1.81(1.22)$ & $-2.00(0.99)^{*}$ & $-0.08(0.20)$ \\
\hline & Women's Rights & $-0.22(1.12)$ & $-0.16(0.87)$ & $0.05(0.20)$ \\
\hline & Police Brutality & $-2.14(1.94)$ & $-0.80(1.25)$ & $0.27(0.30)$ \\
\hline & Trump & $-0.05(0.98)$ & $0.22(0.74)$ & $0.02(0.17)$ \\
\hline & Politics & $3.60(1.24)^{* *}$ & $2.32(1.06)^{*}$ & $-0.46(0.19)^{*}$ \\
\hline & Equality & $3.45(1.18)^{* *}$ & $2.17(1.00)^{*}$ & $0.18(0.20)$ \\
\hline & Religion & $2.25(1.50)$ & $0.34(1.18)$ & $0.04(0.24)$ \\
\hline & Log Likelihood & \multirow{7}{*}{\multicolumn{2}{|c|}{$\begin{array}{c}-199.61 \\
655.51 \\
261 \\
0.90 \\
0.82\end{array}$}} & -312.37 \\
\hline & $\mathrm{BIC}$ & & & 853.13 \\
\hline & Num. obs. & & & 230 \\
\hline & McFadden $\mathrm{R}^{2}$ & & & \\
\hline & McFadden Adj. $R^{2}$ & & & \\
\hline & $\mathrm{R}^{2}$ & & & 0.42 \\
\hline & Adj. $R^{2}$ & & & 0.30 \\
\hline
\end{tabular}

${ }^{* * *} p<0.001,{ }^{* *} p<0.01,{ }^{*} p<0.05$ 